\title{
ANALISIS EFISIENSI BIAYA DENGAN PENDEKATAN STOCHASTIC FRONTIER APPROACH (SFA)
}

(Survey pada Koperasi Baitul Maal Wattamwil Kota Tangerang Selatan

Periode Tahun 2011-2015)

\section{Oleh:}

Ratna Dumilah, S.E., M.M.

\begin{abstract}
ABSTRAK
Efisiensi secara teori adalah parameter yang salah satunya digunakan untuk mengukur tingkat kesehatan suatu lembaga atau perusahaan. Penelitian ini bertujuan untuk mengetahui faktor-faktor yang dapat menyebabkan perbedaan nilai efisiensi biaya.

Populasi pada penelitian ini adalah seluruh Koperasi Baitul Maal Wattamwil (BMT) Kota Tangerang Selatan kategori Koperasi Jasa Keuangan Syariah. Data penelitian adalah data keuangan empat sampel Koperasi BMT yang diperoleh langsung dari Koperasi BMT Kota Tangerang Selatan. Kemudian, data tersebut dibagi menjadi variabel yang tergolong sebagai input dan output. Penentuan variabel pada penelitian ini menggunakan pendekatan parametrik, Stochastic Frontier Approach (SFA). Variabel tersebut terdiri dari Total Pembiayaan, Penempatan pada Bank/BMT lain, Biaya Tenaga Kerja, Beban Bagi Hasil, Total Biaya dan dibandingkan dengan Total Aktiva.

Metode yang digunakan dalam penelitian ini diukur dalam presentase (rasio). Yang mendekati $100 \%$ berarti Koperasi BMT yang paling efisien. Selama periode penelitian (2011-2015), tingkat efisiensi yang dihasilkan dibandingkan antara satu Koperasi BMT dengan Koperasi BMT lain dalam sampel. Hal ini akan menyiratkan bahwa satu Koperasi BMT merupakan Koperasi BMT paling efisien disetiap tahun jika diukur secara relatif terhadap yang lain.Hasil analisis panel data dari penelitian ini menunjukan nilai KBMT Al Fath IKMI 86,84\%, KBMT Al Munawwarah 97,36\%, KBMT Mekar Dakwah 97,62\% dan KBMT UMJ 97,25\% . Dan skor tertinggi adalah Koperasi BMT Mekar Dakwah.
\end{abstract}

Kata Kunci: Efisiensi, Koperasi, Baitul Maal Wattamwil, Stochastic Frontier Analysis

\section{ABSTRACT}

Efficiency as a theory is a parameter that one of each used to measure the best level of an organization or a company. The aim of this research is to know the factors that can cause the different of the expense efficiency value.

Population in this research were all the Cooperation Baitul Maal Wattamwil (BMT) South Tangerang City on the cathegory Cooperation Syaria Finance Service. The research data were the finance data of four samples Cooperation BMT which were got direct from Cooperation BMT South Tangerang City. Then, the data divided to the variable that classified as input and output. The determination of variable in this research used parametric approach "Stochastic Frontier Approach (SFA)". The variable consist of the total of expense, the total of rplacement at Bank or another BMT, the charge of employee, the charge of sharing cost, the total of expense and compared to the total of assets.

The method that was used in this research measured on percentage (ratio). The one that closed to $100 \%$ means that is was the most efficient Cooperation BMT. As long as the 


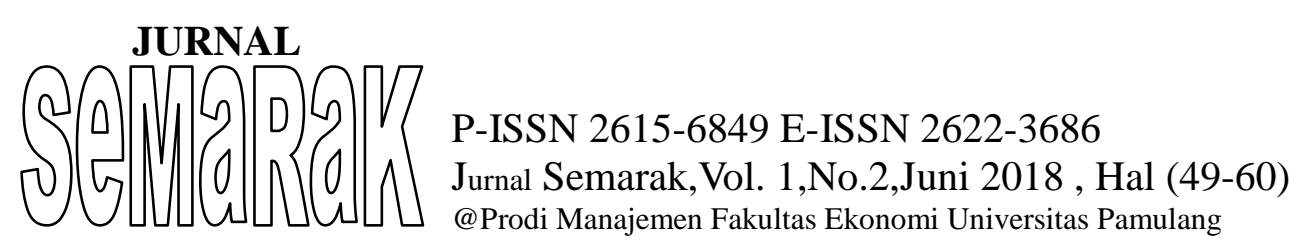

research period (2011-2015), the efficiency level that was resulted compared between one Cooperation BMT and another Cooperation BMT in samples. This was implied that one of Cooperation BMT was the most efficient Cooperation BMT every year if it was calculated relatively to the others.

The result of panel data analysis in this research showed the value of Cooperation BMT Al Fath IKMI 86,84\%, Cooperation BMT Al Munawarrah 97,36\%, Cooperation Mekar Dakwah 97,62\% and Cooperation BMT UMJ 97,25\%. And the highest score was Cooperation BMT Mekar Dakwah.

Key Words :Efficiency, Cooperation, Baitul Maal Wattamwil, Stochastic Frontier Analysis

\section{I.PENDAHULUAN}

\section{A. Latar Belakang}

Banyaknya jumlah Koperasi Syariah yang berdiri di Tangerang Selatan, menjadi nilai plus dari Kabupaten/Kota yang ada di Provinsi

Banten (http://www.tangerangnews.com; 27-082015). Tentu, jumlah koperasi yang besar tersebut adalah asset berharga kota Tangerang Selatan untuk dapat meningkatkan pertumbuhan ekonomi, kesempatan bekerja dan berwirausaha, kesejahteraan dan pengentasan kemiskinan di wilayah Tangerang Selatan. Idealnya, Koperasi sebagai wadah ekonomi kerakyatan dengan integrasi visi pembangunan ekonomi dan sosialnya yang begitu kuat mampu berperan optimal dalam berkontribusi meningkatkan pertumbuhan pembangunan di Tangerang Selatan. Kenyataannya peran ideal koperasi di Tangerang Selatan saat ini belum sepenuhnya dapat terwujud. Banyak koperasi yang masih berkutat di permasalahan internal pengelolaannya. Sejumlah persoalan dengan mudah ditemui seperti: manajemen kepengurusan yang masih sangat tradisional, pembukuan yang belum terstandarisasi, bisnis yang tidak mumpuni, partisipasi anggota yang begitu rendah. Kemampuan mengorganisir diri dan membangun soliditas internal menjadi hal yang tak bisa ditawar, no bargain for these matters, karenanya insan koperasi harus konsen pada prinsip universal koperasi yang salah satunya adalah pendidikan dan training. Melalui pendidikan dan training kepada pengurus dan anggota diharapkan akan mampu meningkatkan kesadaran, spirit, dan kemampuan mengelola dan menjalankan koperasi secara baik juga semangat kebersamaan dalam menjalankan koperasi. Dalam hal ini, perencanaan dan disain pendidikan dan latihan yang baik sangat diperlukan (http://www.dekopindatangsel.or.id; Nur Jamaludin, M.Ec Ketua Pusat Informasi Perkoperasian Dekopinda Tangsel : 17-042015).

Kementerian Koperasi dan UKM terus dan sedang melanjutkan program pemerintah yang melakukan reformasi total koperasi. Tiga langkah reformasi yang digencarkan Kemenkop UKM adalah yang pertama rehabilitasi yaitu membuat database, dari 209.000 jumlah koperasi 62.000 diantaranya telah dibubarkan karena sudah tidak aktif lagi (http://megapolitanpos.com; Jumat 27 Nopember 2015). Selain pembubaran koperasi yang tidak aktif, Kementerian Koperasi dan UKM juga mengadakan program pemeringkatan berdasarkan kesehatan koperasi. Namun, saat ditanya berapa banyak koperasi aktif yang makin sehat dan naik kelas berdasarkan volume usaha dan jumlah anggotanya, Kementerian tak memiliki data yang jelas. Menurut Agus, data yang dimiliki untuk mengetahui koperasi yang sukses mengembangkan

usahanya, hanyalah berdasarkan jumlah anggota, jumlah modal sendiri, jumlah modal dari luar, dan jumlah sisa 


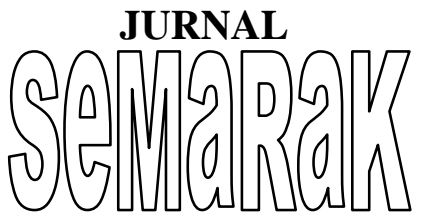

hasil usaha [SHU]

(http://www.teropongsenayan.com;

Sabtu,15-10-2016 : Sekretaris Kementerian

Koperasi dan UKM Agus Muharram).

Salah satu aspek yang diperlukan untuk meningkatkan kontribusi koperasi Tangerang Selatan adalah dengan mengaktifkan jaringan koperasi. Jaringan koperasi di Tangerang Selatan ini sebenarnya sudah terbentuk seperti lahirnya garasi (gerakan koperasi) Tangerang Selatan yakni perhimpunan beberapa koperasi di Tangerang Selatan, Himpunan koperasi syariah (Himkopsyah) Tangsel, forum komunikasi koperasi Tangerang Selatan dan dalam bentuk yang formal ada juga organisasi Dekopinda sebagai wadah resmi yang menaungi Koperasi seTangerang Selatan.Namun, dalam geraknya fungsi pembangunan jaringan yang lebih produktif masih belum mampu dilaksanakan (http://www.dekopindatangsel.or.id; Nur Jamaludin, M.Ec (Ketua Pusat Informasi Perkoprasian Dekopinda Tangsel ; 17 04-2015).

Koperasi sebagai business entity tidak terlepas dari kegiatan-kegiatan untuk memacu rasionalitas dan meningkatkan efisiensi. Efisiensi dalam koperasi dapat dilihat dalam lima lingkup, yakni efisiensi intern, efisiensi alokatif, efisiensi ekstern, efisiensi yang dinamis dan efisiensi sosial (Mutis Thoby; 2004:45).

Berdasarkan uraian diatas penulis ingin melakukan penelitian terhadap beberapa koperasi mengenai "Analisis Efisiensi Biaya dengan Pendekatan Stochastic Frontier Approach (SFA)" survey pada Koperasi Baitul Maal Wattamwil Kota Tangerang Selatan Periode Tahun 2011-2015,

mengingat efisiensi adalah ketepatan cara (usaha,kerja) dalam menjalankan sesuatu (dengan tidak membuang waktu, tenaga, biaya) atau kedayagunaan/ketepatgunaan/kesangkila $\mathrm{n}$ (Kamus Besar Bahasa Indonesia) dengan harapan koperasi sebagai wadah ekonomi kerakyatan dengan integrasi visi pembangunan ekonomi dan sosialnya yang begitu kuat mampu berperan optimal dalam berkontribusi meningkatkan pertumbuhan pembangunan di Kota Tangerang Selatan.

Guna membatasi pembahasan, penulis merumuskan pokok permasalahan akan terfokus pada ;

1. Berapa tingkat efisiensi biaya masing-masing koperasi BMT Kota Tangerang Selatan selama periode 2011-2015 berdasarkan pendekatan Stochastic Frontier Approach?

2. Berapa tingkat efisiensi biaya secara keseluruhan koperasi BMT Kota Tangerang Selatan selama periode 2011-2015 berdasarkan pendekatan Stochastic Frontier Approach?

3. Variabel-variabel apa saja yang memiliki pengaruh besar terhadap tingkat efisiensi biaya pada masingmasing dan secara keseluruhan koperasi BMT Kota Tangerang Selatan?

\section{METODOLOGI PENELITIAN}

Tempat penelitian adalah Koperasi Baitul Maal Wattamwil dengan kategori koperasi jasa keuangan syariah yang terletak di Kota Tangerang Selatan.Waktu penelitian dilakukan pada tahun 2017.

Menurut Sugiyono (2008:31) "Penelitian kuantitatif dapat diartikan sebagai metode penelitian berlandaskan pada filsafat positivsm, digunakan untuk meneliti pada populasi atau sampel tertentu, pengumpulan data

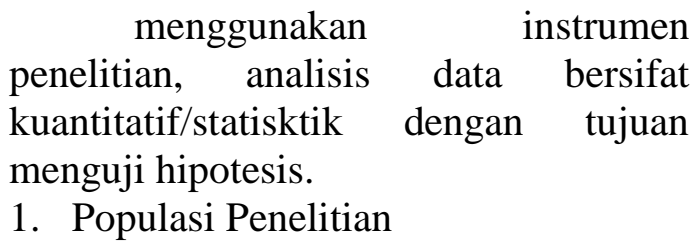


Populasi dalam penelitian ini adalah seluruh koperasi BMT yang tercatat di Dinas Koperasi Kota Tangerang Selatan yang berjumlah 10(sepuluh) koperasi BMT. Dari seluruh populasi akan diambil beberapa koperasi BMT untuk dijadikan sampel.

2. Sampel Penelitian

Sampel Koperasi BMT Kota Tangerang Selatan

\begin{tabular}{|l|l|}
\hline No. & Nama Koperasi BMT \\
\hline 1 & KJKS BMT Al Fath IKMI \\
\hline 2 & KJKS BMT Al Munawwarah \\
\hline 3 & BMT Mekar Dakwah \\
\hline 4 & BMT UMJ \\
\hline \multicolumn{2}{|c|}{ Adapun definisi variabel-variabel yang } \\
\hline
\end{tabular}

Adapun definisi variabel-variabel yang digunakan dalam penelitian ini adalah sebagai berikut;

1. Total Biaya (TC) sebagai variabel terikat (Y), berasal dari berasal dari (Total Pendapatan dikurangi dengan Sisa Hasil Usaha ) : Total aktiva

2. Variabel bebas $(\mathrm{X})$ :

Komponen Input, terdiri dari ;

a. Beban Tenaga Kerja (P1) berasal dari (penjumlahan total biayabiaya gaji pengelola, pengurus dan pengawas) : Total aktiva

b. Beban Bagi Hasil (P2) berasal dari (penjumlah beban bagi hasil dan bonus wadiah yang diberikan kepada pemilik dana pihak ketiga) : Total aktivaVariabel bebas (X): Komponen Output, terdiri dari ; Total Pembiayaan $\left(\mathrm{Q}_{1}\right)$ dan Penempatan pada Bank/BMT lain $\left(\mathrm{Q}_{2}\right)$

Komponen Output, terdiri dari ;

a. Pembiayaan (Q1) berasal dari (penjumlahan total seluruh

b. produk pembiayaan yang diberikan kepada mitra-mitra koperasi BMT) : Total aktiva

c. Penempatan pada Bank/BMT lain (Q2) berasal dari (penjumlahan dana-dana yang ditempatkan pada beberapa Bank/BMT lain) : Total aktiva.

Penelitian ini mengumpulkan data dan teori yang relevan terhadap masalah yang diteliti dengan melakukan studi pustaka terhadap literature dan bahan pustaka lainnya seperti artikel, jurnal, buku dan penelitian terdahulu.

Data yang digunakan dalam penelitian iniadalahdata sekunder yang berupa laporan keuangan masingmasing koperasi sebagaimana tertera pada tabel 3.3.yang telah dipublikasikan dalam Rapat Anggota Tahunan (RAT) pada tiap-tiap tahunnya, sedangkan untuk perhitungan efisiensi biaya itu sendiri dengan metode parametrik membutuhkan fungsi biaya sebagai frontier untuk mengetahui tingkat efisiensi suatu koperasi. Untuk melakukan perhitungan efisiensi dibutuhkan pula input dan output, ada berbagai pendekatan untuk menentukan input dan output dalam mengukur efisiensi.

Dalam penelitian ini penentuan input dan output dari suatu koperasi BMT menggunakan asset approach dengan pertimbangan sebagai berikut ;Sebagian besar penelitian yang pernah dilakukan untuk mengukur efisiensi perbankan adalah dengan menggunakan asset approach. Dengan menggunakan pendekatan ini, maka mudah untuk dilakukan penelitian-penelitian selanjutnya yang berkaitan dengan efisiensi koperasi BMT yang mana koperasi BMT ini merupakan salah satu lembaga keuangan yang memiliki kinerja layaknya sebuah Bank, dan membandingkan hasil penelitian ini

dengan penelitian-penelitian yang pernah dilakukan sebelumnya.

Model analisis SFA dalam penelitian ini mengacu pada fungsi Cobb Douglas yang dilakukan beberapa penyesuaian, sebagai berikut: 
$\operatorname{lnTC} C_{i}=\alpha_{0}+\alpha_{1} \ln \mathrm{P}_{1, i}+\alpha_{2} \operatorname{lnP} 2_{, i}+\alpha_{3}$ $\ln \mathrm{Q}_{1, i}+\alpha_{4} \ln \mathrm{Q}_{2, i}+v_{\mathrm{i}}-u_{\mathrm{i}}$

Atau,

$\operatorname{lnTC} C_{\mathrm{i}}=\alpha_{0}+\alpha_{1} \ln \mathrm{P}_{1, i}+\alpha_{2} \ln \mathrm{P} 2_{, i}+\alpha_{3}$ $\ln \mathrm{Q}_{1, i}+\alpha_{4} \ln \mathrm{Q}_{2, i}+\mathrm{e}_{\mathrm{i}}$

Dengan $e_{\mathrm{i}}=v_{\mathrm{i}}-u_{\mathrm{i}}$ dimana indeks $i=$ $1,2, \ldots, \mathrm{n}$ dengan $\mathrm{n}$ adalah banyaknya data pengamatan

$\operatorname{lnTC}=$ Total Biaya yang dikeluarkan oleh Koperasi

$\ln \mathrm{P}_{1}=$ Beban Tenaga Kerja

$\ln \mathrm{P}_{2}=$ Beban Bagi Hasil

$\ln \mathrm{Q}_{1}=$ Total Pembiayaan

$\ln \mathrm{Q}_{2}=$ Penempatan pada Bank/BMT lain

Rumusan cost frontier menggunakan rumus (2.8) dengan dilakukan beberapa penyesuaian sebagai berikut;

$\mathrm{CEFF}_{\mathrm{i}}=\frac{\check{T} \hat{C}_{\text {min }}}{\check{T} \hat{C}_{i}}=$
$\frac{\exp \left[\alpha_{0}+\alpha_{1} \ln P_{1, i}+\alpha_{2} \ln P_{2, i}+\alpha_{3} \ln Q_{1, i}+\alpha_{4} \ln Q_{2, i}\right] \cdot \exp \left[e_{\min }\right]}{\exp \left[\alpha_{0}+\alpha_{1} \ln P_{1, i}+\alpha_{2} \ln P_{2, i}+\alpha_{3} \ln Q_{1, i}+\alpha_{4} \ln Q_{2, i}\right] \cdot \exp \left[e_{i}\right]}$
$\mathrm{CEFF}_{\mathrm{i}}=\frac{\check{T}_{\operatorname{C}} \hat{C}_{\min }}{\check{T} \hat{C}_{i}}=\frac{\exp \left[e_{\min }\right]}{\exp \left[e_{i}\right]}=$ $\frac{C_{\min }}{C_{i}}$

Koperasi BMT membentuk aktiva produktif (earning assets) melalui fungsi intermediasi, dengan demikian struktur biaya Koperasi BMT dapat diklasifikasikan sebagai fungsi dari vektor output (earning assets), vektor harga input, kesalahan acak (random error) dan tingkat inefisiensi. Tingkat efisiensi biaya berada antara 0 sampai 1 . Tingkat efisiensi 1 menunjukan tingkat efisiensi optimal yaitu $100 \%$.

Metode SFA menggunakan nilai $u$ (error yang dapat dikendalikan) untuk mendapatkan nilai efisiensi, karena dalam metode SFA error component $(u)$ merupakan dasar perhitungannya. Didalam analisis efisiensi biaya, nilai u

yang diperoleh merupakan nilai efisiensi biaya (Kumbhakar dan Lovell, 2000).

Dalam Stata 13.0 Model SFA diuji dengan likelihood-ratio test of sigma_u $=0$ untuk menguji apakah sampel data dapat dikerjakan untuk model cross section (frontier) atau model panel (xtfrontier). Selanjutnya untuk memperoleh nilai efisiensi biaya menggunakan perintah predict te. Saat ini nilai efisiensi sudah ada barulah dilakukan komparasi.Selanjutnya dilakukan uji statistik untuk melihat pengaruh variabel input-output terhadap total biaya dalam stata 13.0 dilakukan uji statistik sebagai berikut;

a. Uji koefisien determinasi $\left(\mathrm{R}^{2}\right)$ untuk mengukur seberapa jauh kemampuan model dalam menerangkan variasi variabel dependen. Nilai koefisien determinasi menunjukan hubungan pengaruh antara dua variabel yaitu variabel independen dan variabel dependen.

b. Uji Wald (Uji Chi-Square) untuk melihat pengaruh serentak atau simultan dari variabel independen terhadap variabel dependen. Penilaian tersebut terpenuhi apabila nilai P-value (Sig.) $\leq \alpha$ dengan $\alpha$ ditentukan sebesar $5 \%$.

c. Uji Z untuk mengetahui apakah terdapat pengaruh secara parsial dari variabel independen terhadap variabel dependen. Pengujian ini menunjukan pengaruh yang signifikan apabila nilai $\mathrm{P}$-value (Sig.) $\leq \alpha$ dengan $\alpha$ ditentukan sebesar 5\%.

Dalam penelitian ini, efisiensi biaya koperasi BMT pada dasarnya dipengaruhi oleh variabel input dan output yang akan membentuk suatu model prediksi cost frontier yang akan diestimasi dan menghasilkan nilai

efisiensi sehingga dapat dilakukan komparasi. Berdasarkan hal tersebut maka peneliti merumuskan hipotesis sebagai berikut:

Hipotesis 1

$\mathrm{H}_{0}=$ Koperasi BMT Kota Tangerang Selatan efisien 
$\mathrm{H}_{1}=$ Koperasi BMT Kota Tangerang Selatan tidak efisien

Selanjutnya diteliti pengaruh variabel input output terhadap total biaya. Berdasarkan hal tersebut maka peneliti merumuskan hipotesis sebagai berikut;

Hipotesis 2

$\mathrm{H}_{0}=$ Tidak ada pengaruh serentak/bersama $\ln \mathrm{P}_{1}, \ln \mathrm{P}_{2}, \ln \mathrm{Q}_{1}$ dan $\ln \mathrm{Q}_{2}$ terhadap $\ln \mathrm{TC}$

III.HASIL PENELITIAN DAN PEMBAHASAN

Deskripsi dari masing-masing variabel penelitian adalah sebagai berikut; Tabel 4.7.

Statistik Deskriptif 4(empat) Koperasi BMT Periode Tahun 2011-2015

\begin{tabular}{llllll} 
& Variabel & Mean & Std.Dev & Min & Max \\
\hline Dependen $(Y)$ & Total Cost & 0.17291 & 0.03785 & 0.11742 & 0.22887 \\
Independen $(\mathrm{X}) ;$ Output & Total Pembiayaan & 0.69055 & 0.10229 & 0.45531 & 0.81668 \\
& Pen.pada Bank/BMT lain & 0.19851 & 0.11585 & 0.05700 & 0.55260 \\
Independen $(\mathrm{X}) ;$ Input & Beban Tenaga Kerja & 0.08251 & 0.02222 & 0.04946 & 0.11684 \\
& Beban bagi Hasil & 0.03771 & 0.02205 & 0.00352 & 0.08194
\end{tabular}

Dari Tabel 4.7. dapat diketahui variabel dependent (Y) berupa total biaya/total cost (TC), variabel independen (X) berupa total pembiayaan/total aktiva $\left(\mathrm{Q}_{1}\right)$, penempatan pada Bank/BMT lain/total aktiva $\left(\mathrm{Q}_{2}\right)$, beban tenaga kerja/total aktiva $\left(\mathrm{P}_{1}\right)$ dan beban bagi hasil/total aktiva $\left(\mathrm{P}_{2}\right)$, selama 5(lima) tahun memiliki perbedaan nilai standar deviasi $<12 \%$ hal ini menggambarkan bahwa kisaran/nilai data pada variabel ini tidak terlalu beragam/berbeda atau tidak terlalu mencolok antara koperasi BMT yang satu dengan yang lainnya.

Korelasi antar Variabel Bebas

.corr $\operatorname{lntc} \operatorname{lnq} 1 \operatorname{lnq} 2 \operatorname{lnp} 1 \operatorname{lnp} 2$ (obs=20)

\begin{tabular}{|c|c|c|c|c|c|}
\hline & $\operatorname{lntc}$ & $\operatorname{lnq} 1$ & $\operatorname{lnq} 2$ & $\operatorname{lnp} 1$ & $\operatorname{lnp} 2$ \\
\hline $\operatorname{lntc}$ & 1.0000 & & & & \\
\hline $\operatorname{lnq} 1$ & 0.6535 & 1.0000 & & & \\
\hline $\operatorname{lnq} 2$ & -0.7463 & -0.8395 & 1.0000 & & \\
\hline $\operatorname{lnp} 1$ & 0.8255 & 0.3659 & -0.5483 & 1.0000 & \\
\hline $\operatorname{lnp} 2$ & 0.7486 & 0.4940 & -0.5501 & 0.5840 & 1.0000 \\
\hline
\end{tabular}

Dari tabel 4.8. yang dianalisis berdasarkan matriks logaritma natural (ln) dari 
JURNAL

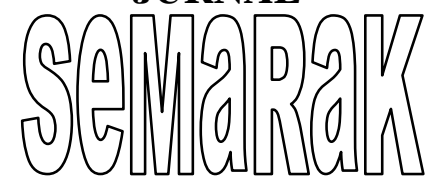

P-ISSN 2615-6849 E-ISSN 2622-3686

Jurnal Semarak,Vol. 1,No.2,Juni 2018 , Hal (49-60)

@Prodi Manajemen Fakultas Ekonomi Universitas Pamulang

masing-masing variabel menunjukan bahwa tidak ada masalah multikolinieritas dalam model.Dari hasil cross section Stochastic Frontier Analysisuntuk uji likelihood-ratio test of sigma_u=0diperoleh output sebagai berikut;

Tabel 4.10 .

Hasil Cross Section Stochastic Frontier Analysis

Likelihood-ratio test of sigma_u $=0$ : $\operatorname{chibar} 2(01)=12.18$ Prob $>=$ chibar2 $=0.000$

Hasil yang diperoleh adalah P-value sebesar 0.000 (P-value $<0.05$ ), sehingga pengujian disimpulkan bahwa sampel data tidak cocok dikerjakan dengan Stochastic Friontier Analysis untuk model cross-section (frontier).

Fokus pembahasan dalam penelitian ini dilakukan pada hasil estimasi frontier yaitu skor efisiensi, hasil pengolahan data berupa efisiensi koperasi BMT yang menjadi sampel penelitian sangat baik, terlihat pada tabel 4.11.;

Tingkat Efisiensi Biaya Koperasi BMT

\begin{tabular}{|l|l|l|l|l|l|l|}
\hline \multirow{2}{*}{ No } & \multirow{2}{*}{ Nama Koperasi BMT } & \multicolumn{6}{l}{$\begin{array}{l}\text { Tingkat Efisiensi } \\
\% / \text { Biaya Koperasi BMT (dalam }\end{array}$} \\
\cline { 3 - 7 } & & 2011 & 2012 & 2013 & 2014 & 2015 \\
\hline 1 & BMT AL FATH IKMI & 77,712 & 74,432 & 93,420 & 96,563 & 100 \\
\hline 2 & BMT AL MUNAWWARAH & 92,105 & 99,859 & 97,126 & 100 & 97,206 \\
\hline 3 & BMT MEKAR DAKWAH & 85,855 & 100 & 82,561 & 80,114 & 100 \\
\hline 4 & BMT UMJ & 100 & 97,437 & 94,454 & 97,388 & 94,154 \\
\hline
\end{tabular}

Dari hasil panel data Stochastic Frontier Analysis diperoleh output sebagai berikut:

Hasil Panel Data Stochastic Frontier Analysis

. xtfrontier lntc lnq1 lnq2 lnp1 lnp2, ti

Time-invariant inefficiency model

Group variable: id

$\begin{array}{lll}\text { Number of obs } & = & 20 \\ \text { Number of groups } & = & 4 \\ \text { Obs per group: min } & = & 5 \\ \text { avg } & = & 5 \\ \text { max } & = & 5 \\ \text { Wald chi2(4) } & = & 108.06 \\ \text { Prob }>\text { chi2 } & = & 0.0000\end{array}$

Log likelihood $=21.512229$

Prob > chi2

[95\% Conf. Interval]

\begin{tabular}{|c|c|c|c|c|c|c|}
\hline $\operatorname{lntc}$ & |Coef. & Std. Err. & $\mathrm{z}$ & $\mathrm{P}>|\mathrm{z}|$ & [95\% Conf. & Interval] \\
\hline $\operatorname{lnq} 1$ & $\mid .3340689$ & .2078725 & 1.61 & 0.108 & -.0733537 & .7414914 \\
\hline $\operatorname{lnq} 2$ & |.0396694 & .1463095 & 0.27 & 0.786 & -.2470919 & .3264308 \\
\hline $\operatorname{lnp} 1$ & |.5651632 & .2331751 & 2.42 & 0.015 & .1081484 & 1.022178 \\
\hline $\operatorname{lnp} 2$ & |.0749458 & .0341534 & 2.19 & 0.028 & .0080064 & .1418851 \\
\hline _cons & .1744069 & .9732678 & 0.18 & 0.858 & -1.733163 & 2.081977 \\
\hline$/ \mathrm{mu}$ & |-13.49968 & 197.8195 & -0.07 & 0.946 & -401.2188 & 374.2194 \\
\hline /nsigma2 & -.2781203 & 14.51487 & -0.02 & 0.985 & -28.72674 & 28.17049 \\
\hline /ilgtgamma & 4.952018 & 14.66121 & 0.34 & 0.736 & -23.78342 & 33.68746 \\
\hline
\end{tabular}

$\begin{array}{llllc}\text { sigma2 } & \mid .7572057 & 10.99074 & 3.34 \mathrm{e}-13 & 1.72 \mathrm{e}+12 \\ \text { gamma } & \mid .9929805 & .1021921 & 4.69 \mathrm{e}-11 & 1\end{array}$


JURNAL

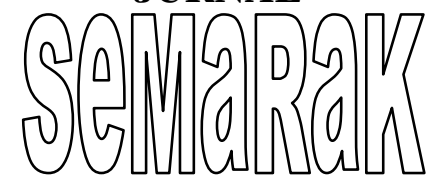

P-ISSN 2615-6849 E-ISSN 2622-3686

Jurnal Semarak, Vol. 1,No.2,Juni 2018 , Hal (49-60)

@ Prodi Manajemen Fakultas Ekonomi Universitas Pamulang

$\begin{array}{lllll}\text { sigma_u2 } & .7518905 & 10.99093 & -20.78995 & 22.29373 \\ \text { sigma_v2 } & 1.0053152 & .002375 & .0006602 & .0099702\end{array}$

Bentuk model prediksi tingkat efisiensi koperasi berdasarkan hasil panel data sebagai berikut:

$\ln \mathrm{TC}=0.1744+0.334 \ln \mathrm{Q}_{1}+0.0396 \ln \mathrm{Q}$ ${ }_{2}+0.5651 \ln \mathrm{P}_{1}+0.0749 \ln \mathrm{P}_{2}$

Berdasarkan hasil analisis SFA diperoleh bahwa variabel $\mathrm{Q}_{1}, \mathrm{Q}_{2}, \mathrm{P}_{1}$ dan $\mathrm{P}_{2}$ berpengaruh signifikan terhadap TC, keempatnya dengan arah positif, sehingga peningkatan

ataupun penurunan keempat nilai variabel tersebut akan mempengaruhi peningkatan ataupun penurunan total biaya sebesar koefisien masing-masing variabel. Efisiensi koperasi BMT yang menjadi sampel penelitian untuk model panel data (xtfrontier), sebagai berikut;

Tingkat Efisiensi Biaya Koperasi BMT

\begin{tabular}{|l|l|l|}
\hline No. & \multicolumn{1}{|c|}{ Nama Koperasi BMT } & $\begin{array}{c}\text { Tingkat Efisiensi Biaya Koperasi BMT } \\
\text { pada kurun waktu 5 tahun }\end{array}$ \\
\hline 1 & BMT AL FATH IKMI & 0.8684 \\
\hline 2 & BMT AL MUNAWWARAH & 0.9736 \\
\hline 3 & BMT MEKAR DAKWAH & 0.9762 \\
\hline 4 & BMT UMJ & 0.9725 \\
\hline
\end{tabular}

Dari keempat Koperasi BMT yang diteliti tingkat efisiensinya cukup baik dan mendekati angka $1(100 \%)$ dan tingkat efisiensi terbaik jatuh pada Koperasi BMT Mekar Dakwah dengan tingkat efisiensi 97.62\%.Sehingga dapat disimpulkan untuk hipotesis 1 bahwa $\mathrm{H}_{0}=$ Koperasi BMT Kota Tangerang Selatan efisien diterima dan $\mathrm{H}_{1}=$ Koperasi BMT Kota Tangerang Selatan tidak efisien ditolak.

2. Analisis Uji Pengaruh Seluruh Variabel terhadap Total Biaya

a. Dari hasil pengujian, dihasilkan nilai statistik uji Chi-Square (Wald chi2(4)) sebesar 108.06 dan P-value (Prob > chi2) sebesar 0.0000 sehingga pengujian dapat disimpulkan bahwa terdapat pengaruh serentak/bersama $\operatorname{lnP} 1$, $\ln \mathrm{P} 2, \operatorname{lnQ} 1$ dan $\ln \mathrm{Q} 2$ terhadap $\ln \mathrm{TC}$, karena P-value $<$ 0.05.Sehingga dapat disimpulkan bahwa untuk Hipotesis 2 bahwa $\mathrm{H}_{0}=$ Tidak ada pengaruh serentak/bersama $\ln \mathrm{P}_{1}$, $\ln \mathrm{P}_{2}, \ln \mathrm{Q}_{1}$ dan $\ln \mathrm{Q}_{2}$ terhadap $\operatorname{lnTC}$ ditolak dan $\mathrm{H}_{1}=$ Terdapat pengaruh serentak/bersama $\ln \mathrm{P}_{1}, \ln \mathrm{P}_{2}, \ln \mathrm{Q}_{1}$ dan $\ln \mathrm{Q}_{2}$ terhadap $\ln \mathrm{TC}$ diterima.

b. Menguji individu koefisien regresi dengan uji $\mathrm{Z}$

Pengujian ini dilakukan untuk mengetahui apakah terdapat pengaruh signifikan setiap variabel prediktor terhadap variabel respon (Hipotesis 3). Dari hasil pengujian, dapat memberikan kesimpulan bahwa;

1) Nilai P-value (Sig.) untuk variabel $\ln \mathrm{P}_{1}$ diperoleh sebesar 0.015 (P-value < 0.05) sehingga pengujian dapat disimpulkan bahwa terdapat pengaruh signifikan $\operatorname{lnP}_{1}$ terhadap $\operatorname{lnTC}$ sebesar $0.5651 \quad$ (pengaruh posistif). $\mathrm{H}_{0}$ ditolak dan $\mathrm{H}_{1}$ diterima.

2) Nilai P-value (Sig.) untuk variabel $\ln \mathrm{P}_{2}$ diperoleh sebesar 0.028 (P-value < 0.05) sehingga pengujian dapat disimpulkan bahwa terdapat pengaruh signifikan $\operatorname{lnP}_{2}$ terhadap $\operatorname{lnTC}$ sebesar $0.0749 \quad$ (pengaruh 
JURNAL

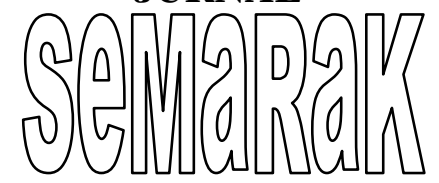

P-ISSN 2615-6849 E-ISSN 2622-3686

Jurnal Semarak, Vol. 1,No.2,Juni 2018 , Hal (49-60)

@ Prodi Manajemen Fakultas Ekonomi Universitas Pamulang

positif). $\mathrm{H}_{0}$ ditolak dan $\mathrm{H}_{1}$ diterima.

3) Nilai P-value (Sig.) untuk variabel $\ln \mathrm{Q}_{1}$ diperoleh sebesar 0.108 (P-value > 0.05) sehingga pengujian dapat disimpulkan tidak terdapat pengaruh signifikan $\operatorname{lnQ}_{1}$ terhadap $\operatorname{lnTC}$ 4) dapat diartikan jika ada kenaikan

5) ataupun pembiayaantidak memiliki pengaruh terhadap total biaya. $\mathrm{H}_{0}$ berikut; ditolak dan $\mathrm{H}_{1}$ diterima.

Hasil Analisis Koefisien Determinasi . corr lntc lntchat $(\mathrm{obs}=20)$

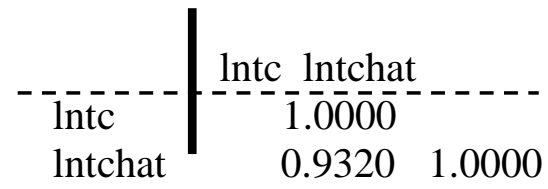

. di r(rho $)^{\wedge} 2$

.86857826

Koefisien Determinasi $\left(\mathrm{R}^{2}\right)$ diperoleh sebesar 0.8686 berarti tingkat hubungan sangat kuat, bahwa keragaman InTC yang mampu dijelaskan $\ln \mathrm{P}_{1}, \ln \mathrm{P}_{2}, \ln \mathrm{Q}_{1}$ dan $\ln \mathrm{Q}_{2}$ secara bersama-sama adalah $86.86 \%$ dengan $13.14 \%$ sisanya dijelaskan oleh error (e) atau variabel lain yang tidak dimasukan kedalam model regresi.

\section{IV.KESIMPULAN DAN SARAN}

\section{A. Kesimpulan}

Berdasarkan hasil analisis dan pembahasan efisiensi biaya pada Koperasi dengan kategori koperasi BMT atau koperasi syariah selama periode tahun 2011-2015 yang telah diuraikan pada bab sebelumnya, dapat ditarik kesimpulan sebagai berikut ;

1. Tingkat efisiensi biaya pada masingmasing Koperasi BMT selama periode tahun 2011-2015 berdasarkan pendekatan Stochastic Frontier Approach model cross section, tingkat efisiensi terkecil
6) Nilai P-value (Sig.) untuk variabel $\operatorname{lnQ} 2$ diperoleh sebesar 0.786 (P-value > 0.05) sehingga pengujian dapat disimpulkan tidak terdapat pengaruh signifikan $\ln _{2}$ terhadap $\ln T C$ dapat diartikan jika ada kenaikan ataupun penurunan penempatan pada Bank/BMT laintidak memiliki pengaruh terhadap total biaya. $\mathrm{H}_{0}$ ditolak dan $\mathrm{H}_{1}$ diterima.

c. Menguji koefisien determinasi $\left(\mathrm{R}^{2}\right)$

Hasil koefisien determinasi sebagai

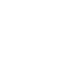


hampir mendekati $100 \%$ dan semua Koperasi BMT menghasilkan angka $>86 \%$. Namun demikian, masih ada biaya yang tidak digunakan atau terbuang dengan sia-sia (inefisiensi $<17 \%$ ).

4. Variabel yang mempengaruhi tingkat efisiensi biaya pada masingmasing Koperasi BMT dan pada Koperasi BMT secara keseluruhan adalah beban tenaga kerja dan beban bagi hasil. Variabel beban tenaga kerja dampaknya sangat tinggi yaitu $56.51 \%$ untuk setiap kenaikan $1 \%$ sedangkan beban bagi hasil dampaknya $7.49 \%$ untuk setiap kenaikan $1 \%$.

\section{B. SARAN}

1. Berdasarkan hasil penelitian yang telah disimpulkan diatas dan dalam upaya menciptakan efisiensi biaya pada Koperasi BMT sebagai implementasi dari hasil pengukuran tingkat efisiensi menggunakan pendekatan stochastic frontier approach, diantaranya adalah ;

a. Membuat struktur organisasi Koperasi BMT lebih ramping. Jika perlu, beberapa divisi yang setelah dievaluasi tidak begitu progress yang memuaskan, dapat digabung atau merger.

b. Menekan beban bagi hasil dan biaya-biaya lain yang tidak perlu sehingga total biaya menjadi lebih kecil dan akan

c. mempengaruhi efisiensi baik secara partial maupun secara simultan.

2. Kepada para pemegang kebijakan dalam Koperasi BMT, disarankan sebagai berikut;

a. Manajemen koperasi harus mempertimbangkan

beberapa unsur pendukung yang dapat mempengaruhi pengendalian biaya secara bertanggung jawab seperti perilaku biaya berpengaruh terhadap kemampuan unit kerja dalam mengendalikan biaya yang menjadi tanggungjawabnya.

b. Manajemen Koperasi BMT harus merancang sistem pengendalian biaya efektif dengan cara sistem pengendalian dan pelaporan biaya yang memisahkan antara biaya yang terkendali dan diluar kendali manajer.

3. Dengan adanya keterbatasan dalam penelitian ini, kepada peneliti lain diharapkan untuk mengadakan penelitian sejenis lebih lanjut dengan mengambil wilayah yang lebih luas, sampel yang lebih banyak dan menggunakan rancangan penelitian yang lebih kompleks, sehingga dapat ditemukan hasil yang lebih optimal dan bisa digeneralisasikan pada wilayah yang lebih luas.

\section{DAFTAR PUSTAKA}

Afin Murtie., Belajar Manajemen dari Konsultasi Strategi, Cetakan Pertama, Laskar

Aksara, 2012.

Agus Sartono., Manajemen Keuangan:Teori dan Aplikasi, Edisi Keempat, 2008.

Bambang Riyanto., Dasar-dasar Pembelanjaan Perusahaan, Edisi Keempat, BPFE,

Yogyakarta, 2001.

Bastian Bustami dan Nurlela, Akuntansi Biaya, Edisi 3, Mitra Wacana Media, 2012.

Deputi Bidang Pembiayaan., Penyempurnaan Pedoman Standar Operasional Manajemen

KJKS/UJKS Koperasi, Kementrian Koperasi Dan Usaha Kecil Dan Menengah 


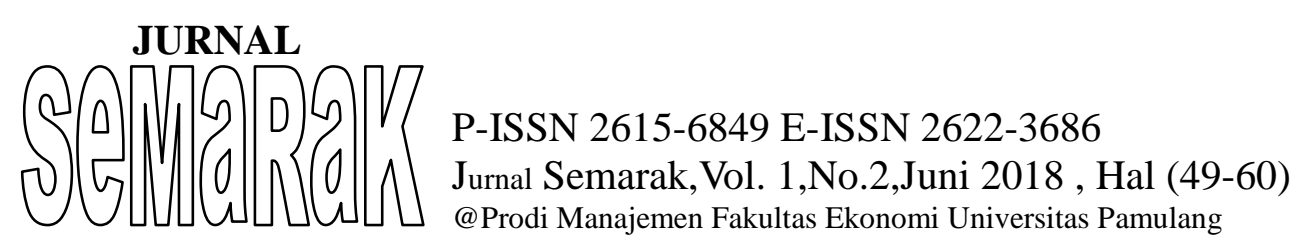

Republik Indonesia, 2015

Dinas Koperasi, Laporan akhir Kualitatif dan $R \& D$, Cetakan Keempat, pemeringkatan koperasi pemerintah kota Alfabeta,

Tangerang

Bandung 2008.

2014.

Selatan 2014, Tangerang Selatan,

Dinas Koperasi Usaha Kecil Dan Menengah., Modul Asistensi Teknis

KUKM:Modul

IV:Kebijakan Koperasi Simpan

Pinjam Dan Unit Simpan Pinjam Koperasi

Pemerintah Kota Tangerang

Selatan, 2010

Heri Sudarsono., Bank dan Lembaga

Keuangan Syariah:Deskripsi dan Ilustrasi,

Edisi 4,

Cet.3, Ekonisia, Yogyakarta, 2015.

Hertanto Widodo dan Teten Kustiawan.,

Akuntansi dan Manajemen Keuangan Untuk

Organisasi Pengelola Zakat,

Cetakan Pertama, $2001 \mathrm{M}$.

Horne dan Machowichz, Fundamental Of

Financing Management Terjemahan

Fitriasari

Dan Kwary, Edisi 12 Buku 1,

Salemba, Jakarta, 2009.

Jochen Ropke, Ekonomi

Koperasi:Teori\&Manajemen, Edisi Kedua,

Cetakan Pertama,

Graha Ilmu, Yogyakarta, 2012.

M. Nur Rianto Al Arif., Pengantar Ekonomi

Syariah : Teori Dan Praktik, Cet.1,

CV.Pustaka Setia, Bandung, 2015.

Nur S. Buchori., Koperasi Syariah, Cetakan

Pertama, September 2009.

Rudianto., Akuntansi Koperasi:Konsep dan

Teknik Penyusunan Laporan Keuangan,

Erlangga, Ciracas, 2010.

Rusmin Tumanggor dan Tim Penyusun.,

Buku Panduan Penulisan Tesis, Program

Pascasarjana, Universitas Pamulang,

2013.

Suharyadi dan Purwanto S.K.,

Statistika:Untuk Ekonomi \& Keuangan Modern,

Edisi 2 Buku 2, Salemba Empat, Jakarta, 2009.

Muhammad Bahanan., Analisis Kinerja BMT-UGT Sidogiri dengan Menggunakan

Pendekatan Balanced Scorecard dan Analytical Hierarchy Process, Universitas

Jember, 2015.

Nurul Komaryatin, Analisis Efisiensi Teknis Industri BPR di Eks Karesidenan Pati,

Universitas Diponegoro, Semarang,

2006

Pandi Afandi., Analisis Kinerja keuangan untuk Mengukur Kesehatan Keuangan Koperasi 


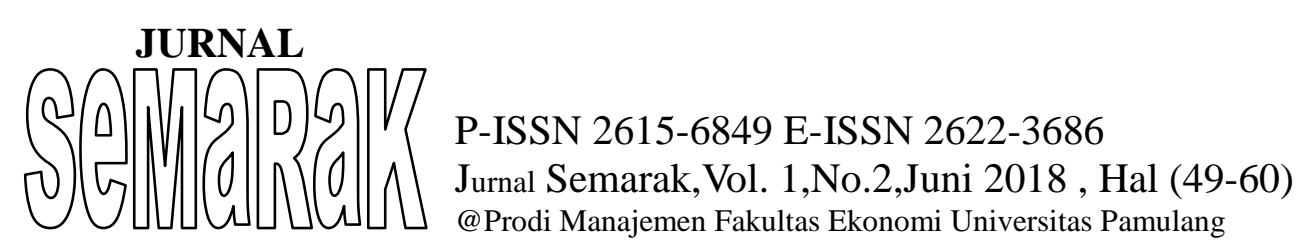

KSU BMT Arafah Kecamatan Undang-Undang Republik Indonesia., Bancak Kabupaten Semarang, STIE AMA Tentang Perkoperasian, Nomor 17 Tahun Salatiga,

2014.

Sulistyani Dyah Pramitasari., Analisis Efisiensi TPI (Tempat Pelelangan Ikan) Kelas 1, 2 2012.

Laporan Keuangan KBMT Al Fath IKMI., Neraca dan Laporan Laba/Rugi, Periode Tahun

2011 sampai dengan Tahun 2015.

$$
\text { dan } 3 \text { Di Jawa Tengah dan }
$$

Pengembangan untuk Peningkatan

Kesejahteraan

Nelayan,Universitas Diponegoro,

Semarang, 2005

Laporan Keuangan KBMT Al

Munawarrah., Neraca dan Laporan Laba/Rugi, Periode 2015.

Peraturan Deputi Bidang Pengawasan Kementerian Koperasi Dan Usaha Kecil Dan

Menengah Republik Indonesia.,

Tentang Pedoman Penilaian Kesehatan Koperasi Simpan Pinjam Dan Unit Simpan Pinjam Koperasi, Nomor 06/Per/Dep.6/IV/2016

Peraturan Menteri Koperasi Dan Usaha Kecil Menengah Republik Indonesia., Tentang

Pelaksanaan Kegiatan Usaha

Simpan Pinjam Dan Pembiayaan Syariah Oleh

Koperasi,

Nomor

16/Per/M.KUKM/IX/2015.

Laporan Keuangan KBMT Mekar Dakwah., Neraca dan Laporan Laba/Rugi, Periode

Tahun 2011 sampai dengan Tahun 2015.

Laporan Keuangan KBMT UMJ., Neraca dan Laporan Laba/Rugi, Periode Tahun 2011

sampai dengan Tahun 2015.

http://economy.okezone.com,

http://megapolitanpos.com dan

http://infobanknews.com,

Kemenkop: Kinerja Koperasi Syariah

Makin Baik, 2016.

http://himkopsyahtangsel.blogspot.co.id,Pe mbentukan Himpunan BMT-BMT Tangsel, 2011.

Peraturan Menteri Negara Koperasi Dan http://megapolitanpos.com, Kemenkop Usaha Kecil Menengah Republik UKM Gencarkan Reformasi Koperasi, Indonesia., Achmad

Tentang Pedoman Standar Operasional Manajemen Koperasi Jasa Keuangan

Syariah Dan Unit Jasa Keuangan Koperasi Syariah Koperasi, Nomor

35.3/PER/M/KUKM/X/2007

Peraturan Menteri Negara Koperasi Dan Usaha Kecil Menengah Republik Indonesia.,

Tentang Standar Operasional Manajemen Koperasi JasaKeuangan Syariah/Unit

Jasa Keuangan Syariah Koperasi, Nomor 35.2/Per/M.KUKM/X/2007. 